\title{
OPHTHALMOLOGIC COMPLICATIONS IN SPINAL SURGERIES: LITERATURE REVIEW
}

\author{
COMPLICAÇÕES OFTALMOLÓGICAS EM CIRURGIAS DA COLUNA VERTEBRAL: \\ REVISÃO DA LITERATURA
}

\section{COMPLICACIONES OFTALMOLÓGICAS EN CIRUGÍAS DE LA COLUMNA VERTEBRAL: REVISIÓN DE LITERATURA}

\author{
João Thiago Frossard da Cruz Ferreira ${ }^{1,2}$ \\ 1. Universidade Federal do Rio de Janeiro, Rio de Janeiro, RJ, Brazil \\ 2. Hospital Universitário Clementino Fraga Filho (HUCFF), Neurosurgery Service, Rio de Janeiro, RJ, Brazil.
}

\begin{abstract}
Literature review using PubMed, relating ophthalmologic complications in spinal surgery. Ischemic optic neuropathy (ION), central retinal artery occlusion (CRAO) and cortical blindness (CB) constitute the majority of cases. These are rare complications and have a poor prognosis. Post-operative visual loss (POVL) occurs most often in surgical procedures performed in the prone position. Being male, anemia, blood transfusion, and prolonged surgery time are related to ION, while malposition and direct compression of the eyeball are related to the development of CRAO. Level of Evidence III; Systematic review ${ }^{b}$ of level III studies.
\end{abstract}

Keywords: General Surgery; Spine; Patient Positioning; Prone Position.

\section{RESUMO}

Revisão da literatura através do PubMed, relacionando complicações oftalmológicas em cirurgias da coluna vertebral. Neuropatia óptica isquêmica (NOI), oclusão da artéria central da retina (OACR) e cegueira cortical (CC) constituem a maior parte dos casos. São complicações raras e possuem prognóstico ruim. A perda visual pós operatória (PVPO), ocorre com maior frequência em procedimentos cirúrgicos realizados na posição prona. Sexo masculino, anemia, transfusão sanguínea e tempo cirúrgico prolongado estão relacionados a NOl, enquanto o mal posicionamento e compressão direta do globo ocular ao desenvolvimento de OACR. Nível de Evidência III; Revisão sistemática ${ }^{b}$ de estudos de nível III.

Descritores: Cirurgia Geral; Coluna Vertebral; Posicionamento do Paciente; Decúbito Ventral.

\section{RESUMEN}

Revisión de la literatura a través de PubMed, relacionando complicaciones oftalmológicas en cirugías de la columna vertebral. Neuropatía óptica isquémica (NOI), oclusión de la arteria central de la retina (OACR) y ceguera cortical (CC) constituyen la mayoría de los casos. Son complicaciones raras y tienen mal pronóstico. La pérdida visual postoperatoria (PVPO) ocurre con mayor frecuencia en procedimientos quirúrgicos realizados en la posición prona. El sexo masculino, la anemia, la transfusión de sangre y el tiempo quirúrgico prolongado están relacionados con la NOl, mientras el mal posicionamiento y la compresión directa del globo ocular se relacionan con el desarrollo de la OACR. Nivel de Evidencia III; Revisión sistemática ${ }^{b}$ de estudios de nivel III.

Descriptores: General Cirugía; Columna Vertebral; Posicionamiento del Paciente; Posición Prona.

\section{INTRODUCTION}

Ophthalmological complications following spinal surgeries are rare, but have serious consequences. They can result in the irreversible loss of visual acuity. The treatment is not very effective and the prognosis is poor in most cases. Cardiac and spinal surgeries are the main types of non-ophthalmological surgeries related to this type of complication.

The objectives of this literature review are to identify the source of the loss of sight, the associated risk factors, preventative measures, and conduct when faced with such cases.

\section{METHODS}

This research is based on a review of the literature published on PubMed related to ophthalmological complications resulting from spine surgery. Seventeen scientific articles were selected for this literature review. The subject has been addressed by various medical specialties, mainly neurosurgery, orthopedics, cardiac surgery, ophthalmology, and anesthesia. Articles that were not associated with ophthalmological complications in spine surgery were discarded.

\section{RESULTS}

A review article about complications related to positioning in surgeries of thee lumbar spine ${ }^{1}$ showed that loss of visual acuity was most often related to the prone and genupectoral positions. The study discussed complications such as conjunctival edema, ischemic optic compartment syndrome, paralysis

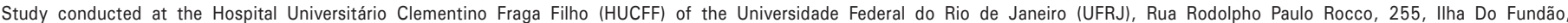
Rio de Janeiro, RJ, 21941-590, Brazil.

Correspondence: Rua Visconde de Pirajá, 330/1006, Ipanema, Rio de Janeiro, RJ, Brasil. joaothiagofrossard@gmail.com 
of the peripheral nerves, skin lesions, thromboembolic complications, dislocation of the shoulder, and lower extremity compartment syndrome.

There was a relationship between prolonged surgical time and an increase in the number of complications in the prone position.

This was a randomized, prospective study that evaluated the intraocular pressure (IOP) associated with the position of the head during lumbar spine arthrodeses. ${ }^{2}$ Fifty-two patients between 18 and 80 years of age were selected. The control group was operated with the head in the neutral position parallel to the ground while the experimental group was operated with the head inclined at 10 degrees. The intraocular pressure was recorded in correspondence with blood pressure and $\mathrm{CO} 2$ pressure. The study concluded that the patients operated with the head elevated had a significantly reduced IOP as compared to the group operated in the neutral position.

A review article researching risk factors for postoperative visual

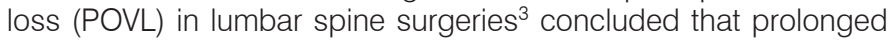
surgical time in a prone position, anemia, hypotension, and blood transfusion are related to ischemic optic neuropathy (ION). There is a risk of central retinal artery occlusion (CRAO) related to incorrect positioning during surgery and cortical blindness (CB) related to the prone position and obesity.

A study evaluating visual loss following spine surgery ${ }^{4}$ showed that the increase in venous pressure, interstitial edema, direct compression, vascular compression, and venous infarction are related to the development of this pathology.

ION is the main cause of POVL, while retinal ischemia, cortical blindness, and posterior reversible encephalopathy syndrome are less common causes. The study showed that the male sex, obesity, prolonged surgical time, large blood loss, use of A Wilson frame, and a reduction in the administration of colloids are possible risk factors for POVL. In most cases, the treatment is not very effective and they are irreversible. Thus, prevention and risk factor modification measures become more important.

In a review of literature published between 1998 and 2008 about $1 \mathrm{ON},{ }^{5}$ most of the cases consisted of males between 30 and 69 years of age who underwent lumbar fusion with surgical time longer than 5 hours and blood loss greater than 1 liter.

A retrospective study evaluated 3450 spine surgeries performed in three institutions ${ }^{6}$ among which 7 cases of POVL were identified $(0.20 \%)$ including ION, CRAO, and CB. Three patients recovered completely and one patient had a partial recovery.

A study addressing the prevalence of POVL in general, spinal, cardiac, and orthopedic surgery ${ }^{7}$ in the United States between 1996 and 2005 evaluated more than 5.6 million patients who underwent surgical procedures using American databases. ION, CRAO, and CB were researched through codes at the time of patient discharge. The study concluded that cardiac surgery and spinal surgery had the highest rates of POVL (8.64/1000 procedures and 3.09/1000 procedures, respectively).

Patients younger than 18 years of age had a higher prevalence of POVL, CB being the main cause. Patients older than 50 years of age had a higher risk of ION and CRAO. The male sex, anemia, and blood transfusion were associated with a greater frequency of POVL. The limitations of the study are the difficulty in obtaining surgical procedure data and the inability of visualizing some of the POVL codes at the time of patient discharge.

A study of POVL in pediatric surgeries for the correction of scoliosis used databases ${ }^{8}$ to evaluate 42,339 patients less than 18 years of age between 2002 and 2011. ION, CRAO, and CB were investigated at the time of discharge and demographic data, comorbidities, and surgical parameters were compared among patients with and without POVL yielding an incidence of 1.6/1000 patients. Younger male patients with a history of anemia and fusion of 8 or more levels were more prevalent among the patients with POVL. CB was present in all the cases.

A retrospective populational study using databases ${ }^{9}$ registered patients submitted to spinal surgery between 1993 and 2002.
Using pathology codes, searches were conducted for ION, CRAO, non-ION POVL, and non-CRAO POVL. There was an incidence of $0.094 \%$. Surgery for correction of scoliosis and lumbar fusion had the highest rates $(0.28 \%$ and $0.14 \%$, respectively). Patients younger than 18 years of age and older than 85 years of age had chances of non-ION and non-CRAO POVL 5.8 and 3.2 times higher, respectively, than patients between 18 and 85 years old. Patients with peripheral vascular disease, hypertension, and those who had blood transfusion developed non-ION and non-CRAO POVL at a higher rate. The incidence of ION was $0.006 \%$. Hypotension, peripheral vascular disease, and anemia were related to ION. Multiple factor analysis was used to identify the risk factors.

A study analyzing ION in spinal arthrodesis surgeries between 1998 and 2012 in the United States ${ }^{10}$ recorded 2,511,073 procedures with ION in 257 patients, 1.02 cases per 10,000 patients. Factors associated with ION were age, blood transfusion, and obesity. The female sex was considered a protection factor.

A case report and literature review of acute closed angle glaucoma (ACAG) following spine surgery ${ }^{11}$ found 4 cases described in the literature, 3 bilateral, and that the use of mydriatic agents and the prone position could be related to the development of this pathology. Unlike the other causes of POVL, ACAG can be treated more effectively if caught early. The diagnosis is difficult because of the late onset of symptoms, generally days following surgery.

\section{DISCUSSION}

Similar findings were encountered in the study analysis. Possible risk factors for ION and CRAO were shared by the authors. Poor prognosis and irreversible symptoms in most cases are described in the articles, but in reference (6), $42.8 \%$ of the patients recovered completely (3 in 7 cases of POVL).

The literature on the subject is mostly comprised of case reports. The lack of randomized studies reduces the level of confidence in the research.

\section{CONCLUSION}

POVL is a rare complication. Cardiac and spine surgery are responsible for most cases: approximately 8 cases per 10,000 cardiac surgeries and 3 cases per 10,000 spine surgeries.

ION, CRAO, and CB are the main causes of POVL. Posterior ION accounts for most cases in spine surgeries, while anterior ION accounts for most cases in cardiac surgeries. Prone position, male sex, prolonged surgical time, anemia, and blood transfusion are related to ION. CRAO is related to bad positioning and direct compression of the eyeball. CB is more common in young patients. In the absence of ophthalmological findings, a cranial imaging examination is indicated to assess occipital infarction or hypophyseal apoplexy.

In general, treatment is not very effective and the prognosis is poor. Prevention measures play a fundamental role in the process.

POVL must be evaluated immediately by the ophthalmologist in order to identify the source and institute treatment. Some causes, such as ACAG have a treatment that is more effective. Measures such as elevation of the headrest of the operating table in higher risk patients reduce IOP and increase blood perfusion of the eyeball, helping to prevent ION. Correct positioning on soft or Mayfield supports with periodic checking of the eyeball during the surgical procedure are CRAO prevention measures.

More randomized studies are necessary to increase the level of evidence of this subject.

$\overline{\text { All authors declare no potential conflict of interest related to }}$ this article. 
CONTRIBUTION OF THE AUTHORS: The author made significant individual contributions to this manuscript. JTFCF (0000-0002-0356-5504)* was responsible for the bibliographical research, the review, and the writing of the manuscript. ${ }^{*} \mathrm{ORCID}$ (Open Researcher and Contributor ID).

\section{REFERENCES}

1. Shriver MF, Zeer V, Alentado VJ, Mroz TE, Benzel EC, Steinmetz MP. Lumbar Spine Surgery Positioning Complications: a Systematic Review. Neurosurg Focus. 2015;39(4):E16.

2. Emery SE, Daffner SD, France JC, Ellison M, Grose BW, Hobbs GR, et al. Effect of Head Position on Intraocular Pressure During Lumbar Spine Fusion: A Randomized, Prospective Study. J Bone Joint Surg Am. 2015:97(22):1817-23.

3. Li A, Siwwney C, Veeravagu A, Bhatti I, Ratliff J. Postoperative Visual Loss Following Lumbar Spine Surgery: A Review of Risk Factors by Diagnosis. World Neurosurg. 2015;84(6):2010-21

4. Nickels TJ, Manlapz MR, Farag E. Perioperative visual loss after spine surgery. World J Orthop. 2014:5(2):100-6

5. Lee LA, Newman NJ, Wagner TA, Dettori JR, Dettori NJ. Postoperative ischemic optic neuropathy. Spine (Phila Pa 1976). 2010;35(9 Suppl):S105-16.

6. Stevens WR, Glazer PA, Kelley SD, Lietman TM, Bradford DS. Ophthalmic Complications After Spinal Surgery. Spine (Phila Pa 1976). 1997:22(12):1319-24.

7. Shen Y, Drum M, Roth S. The prevalence of perioperative visual loss in the United States: a
10 year study from 1996 to 2005 of spinal, orthopedic, cardiac and general surgery. Anesth Analg. 2009;109(5):1534-45.

8. De la Garza-Ramos R, Sandani AF, Sponseller PD, Ain MC, Miller NR, Shaffrey CL, et al. Visual loss after a corrective surgery for pediatric scoliosis: incidence and risk factors from a nationwide database. Spine J. 2016;16(4):516-22

9. Patil CG, Lad EM, Lad SP, Ho C, Boakye M. Visual loss after spine surgery: a populationbased study. Spine (Phila Pa 1976). 2008;33(13):1491-6.

10. Rubin DS, Parakati I, Lee LA, Moss HE, Joslin CE, Roth S. Perioperative Visual Loss in Spine Fusion Surgery: Ischemic Optic Neuropathy in the United States from 1998 to 2002 in the Nationwide Inpatient Sample. Anesthesiology. 2016;125(3):457-64.

11. Stewart RJ, Landy DC, Lee MJ. Unilateral Acute Angle-Closure Glaucoma After Lumbar Spine Surgery: A Case Report and Systematic Review of the Literature. Spine (Phila Pa 1976). 2016;41(5):E297-9. 